\title{
DECLINE OF NATIVE PRAIRIE IN CORE GRASSLAND CONSERVATION AREAS IN SOUTHWESTERN MANITOBA 2010-2015
}

\section{Cary Hamel}

Nature Conservancy of Canada 200-611 Corydon Avenue Winnipeg, MB R3L OP3

cary.hamel@natureconservancy.ca

\section{Rebekah Neufeld}

Nature Conservancy of Canada

270-1570 18th Street

Brandon, MB R7A 5C5

\section{Introduction}

Within the Southwestern Manitoba Mixed-Grass Prairie Important Bird Area (IBA), three perennial grassland blocks represent over 26,300 ha $(65,000$ acres) of habitat within a matrix that is otherwise dominated by annual cropland (Fig. 1). The grassland blocks provide habitat for 12 species assessed as Endangered, Threatened or Special Concern by the Committee on the Status of Endangered Wildlife in Canada or under Manitoba's Endangered Species \& Ecosystems Act. ${ }^{1}$ Ten additional nationally rare or uncommon species also occur in the IBA. Native mixed-grass prairie comprises 40-50 per cent of these blocks, representing some of the last non-fragmented mixed-grass prairie in Manitoba. Non-native perennial grasslands composed primarily of forage mixes for pasture or hay production are also common and are dominated by non-native graminoids and forbs (typically alfalfa). These expansive native-tame grassland complexes represent a significant conservation opportunity for grassland-dependent birds, many of which are area-sensitive. ${ }^{2}$ Some species, such as Sprague's Pipit

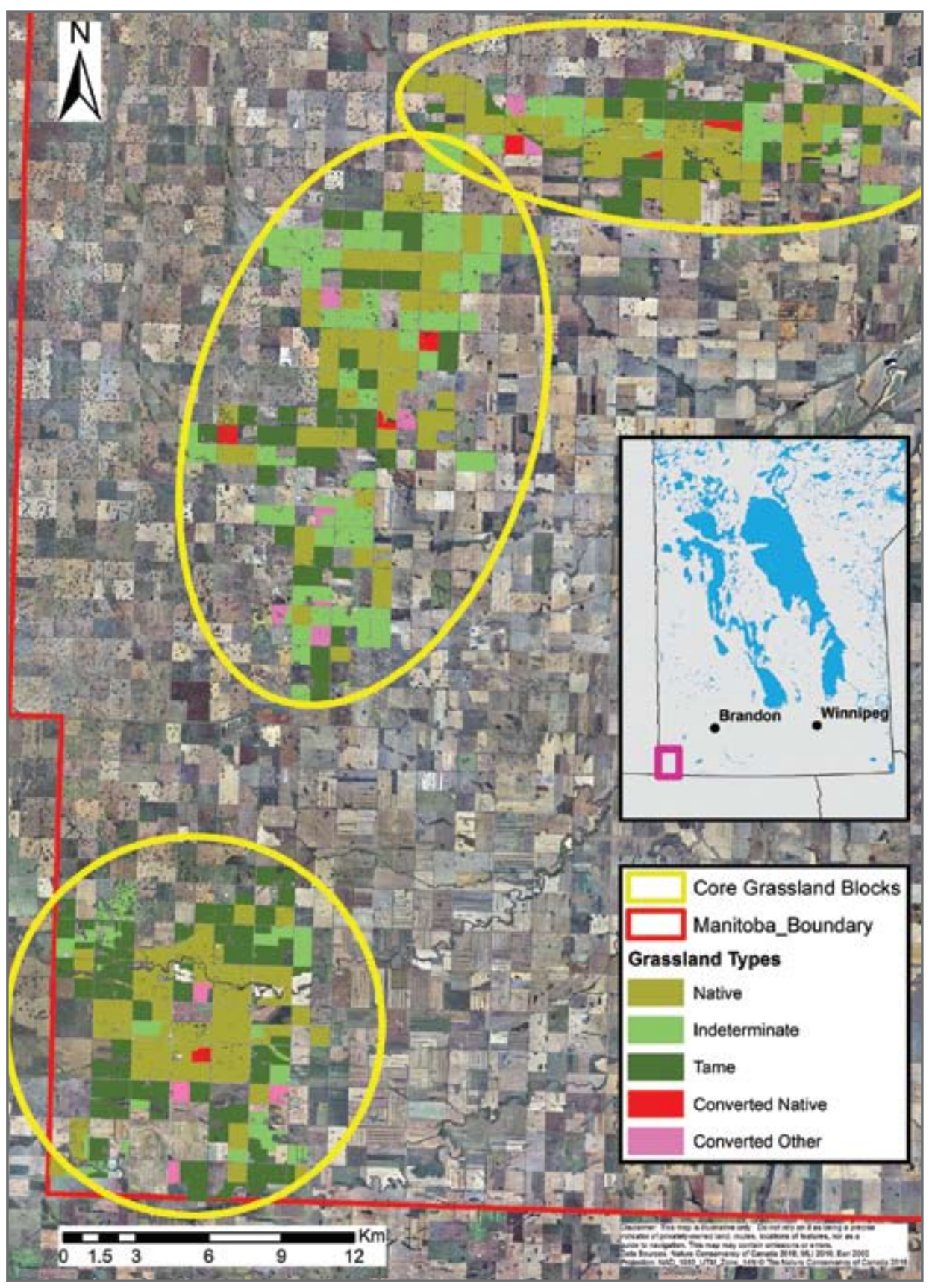

FIGURE 1. Distribution of grassland types and 2010-2015 habitat conversion within core grassland blocks in the Southwestern Manitoba Mixed-grass Prairie Important Bird Area.

(Anthus spragueii) and Chestnutcollared Longspur (Calcarius ornatus), exhibit preferences for native prairie ${ }^{3}$ and rarely occur in, ${ }^{4}$ or near cropland. ${ }^{5}$

The IBA has been a focus of conservation efforts by non- governmental organizations, Crown conservation agencies, and local stewardship groups for more than 15 years, with programming related to land securement, land management, Species At Risk stewardship, and ecotourism. ${ }^{6,7}$ 
Approximately 12 per cent of perennial grasslands in the three blocks are conserved as provincial Crown Wildlife Management Areas, provincial Crown conservation agency-owned lands, environmental non-governmental organizationowned lands, or as private lands secured through perpetual conservation easement agreements. ${ }^{7}$ Within the IBA, no areas are considered permanently protected via legal means from oil, petroleum, aggregate extraction and other development. ${ }^{8}$

The goal of this study was to determine the status and rate of loss of native prairie in three of the largest perennial grassland blocks within the Southwestern Manitoba Mixed-Grass Prairie IBA and to summarize land use changes.

\section{Methods}

Relative to small remnants, large blocks of intact habitat are prioritized by biodiversity conservation organizations as opportunities to conserve disturbance-driven landscape-scale ecological functions and successional heterogeneity. ${ }^{9}$ Fitzgerald et al. ${ }^{10}$ recommend that grassland bird conservation areas be a minimum of 809 ha $(2,000$ acres) "of high quality protected grassland (in a polygon in which edge is minimized) in order to support source breeding populations of high priority bird species." Three blocks within the IBA met these criteria and were the focus of this study (Fig. 1). The grasslands of the nearby Blind River and Souris River valleys, though greater than 809 ha, were not included due to extensive and long-duration flooding which prevented access to much of the area. Grassland blocks smaller than 809 ha in size were excluded.

Systematic surveys were conducted in 2010 and 2015 to document vegetation cover and land management. In 2010, vegetation cover types were mapped as polygons in a shapefile database using ArcMap geographic information system (GIS) software. Polygons were delineated using interpretation of orthophotographs, to a minimum of 3 ha for grassland habitats. Other cover types such as trees, oil and gas development, gravel pits and yard-sites were mapped at a smaller scale $(<1 \mathrm{ha})$ because we could reliably discern these cover types on the orthophotographs and in the field. Polygon boundaries were also delineated by land ownership units, defined by a cadastral layer. Vegetation cover was not classified in ditches and on road allowances. Grassland complexes typically supported interior shallow and ephemeral wetlands. These wetlands were not distinguished from the broader grassland complexes because they were difficult to detect and their extents often vary year to year.

All vehicle-accessible gridroads and road allowances within the survey area were driven, and classification of land cover and land use was conducted by visual interpretation from the vehicle (using binoculars). In the few instances where a portion of a land parcel could not be seen from the road allowance, land cover was interpolated using orthophotography and observed changes, or lack of changes, on adjacent lands. A GPSenabled Juno Trimble was used to edit the GIS database in the field, and each polygon was assigned a category of land cover and land use. Surveys were repeated in 2015 using the same methods. Observers were the same in both 2010 and 2015, with the exception of the southern portion of the southernmost block.

Vegetation communities were divided into six categories:

- native prairie - grasslands which appeared to be dominated by native prairie vegetation or supported species indicative of intact prairie throughout the patch when the dominant cover could not be determined. The latter were still categorized as prairie, despite potential co-dominance of nonnative species, as they may support an in-situ seed source, which could allow for reclamation of prairie species without restoration through planting.

- tame grassland - dominated by non-native grasses and forages, not expected to return to a native prairie without active restoration.

- indeterminate grassland perennial grassland in which the species composition could not be determined using the survey methods. These parcels were typically intensively grazed, or too distant from the observer to make a clear determination.

- annual cropland - areas cultivated and seeded to annual crops and considered non-permanent cover.

- woody vegetation - treedominated areas that were detectable on orthophotographs.

- other - yard sites, dugouts, infrastructure and areas without vegetative cover.

Land Use was divided into three categories:

- grazing - used as pasture for livestock for any period of time.

- haying - harvested for forage.

- idle or undetected - no visible management or could not be determined.

Area was calculated using GIS for each category of cover for the two years of surveys. The difference in area between 2010 and 2015 was calculated as a per cent change over the five years. 


\section{Results}

Across the survey area the overall extent of perennial grasslands was reduced by $2 \%$ (Table 1 ). Patterns differed amongst the three blocks, with a $0.4 \%$ increase in one block and a decrease of $2 \%$ and $4 \%$ in the other two blocks.

Between 2010 and 2015, there was a 3\% decline in the extent of mapped mixed-grass prairie in core grassland blocks (Table 1). Two-thirds was converted into annual cropland and one-third into tame grasslands. Though the area of native prairie within core blocks was roughly equal, the rate of loss was not evenly distributed (Fig. 1). Approximately $4 \%$ was lost in each of two of the blocks and $1 \%$ in the third.

An overall increase in perennial tame grasslands (3\%) was observed as annually cultivated lands were converted to perennial alfalfa hay mixes.

While the conversion of annual cropland into tame grasslands offset tame grassland loss elsewhere, the ratio of management types did show a small change. Across the three blocks there was a $2 \%$ decrease in area under grazing management and a $4 \%$ increase in area under haying management. Of all converted native prairies, over $60 \%$ were in grazing systems post-conversion. All converted annual cropland was put into haying management.

\section{Discussion}

Exceptionally high water levels occurred in 2011 and 2014, resulting in significant flooding that impacted much of the arable land in the study area. It is unclear if observed changes in land cover and land use would be different under drier conditions.

The $0.7 \%$ average annual native prairie loss observed in the IBA is similar to the average annual native
TABLE 1. Hectares of perennial grassland within core grassland blocks in the Southwestern Manitoba Mixed-grass Prairie Important Bird Area, by grassland type.

\begin{tabular}{|l|r|r|r|}
\hline GRASSLAND TYPE & $\mathbf{2 0 1 0}$ & $\mathbf{2 0 1 5}$ & CHANGE \\
\hline Native & $\mathbf{9 9 9 0}$ & $\mathbf{9 6 6 1}$ & $\mathbf{- 3 2 9}$ \\
\hline Tame & 7585 & 7790 & 205 \\
\hline Indeterminate & 5662 & 5391 & -271 \\
Total & $\mathbf{2 3 2 3 7}$ & $\mathbf{2 2 8 4 2}$ & $\mathbf{- 3 9 5}$ \\
\hline
\end{tabular}

grassland loss rates for the broader Canadian prairies $(0.6 \%$ loss/year 1985-2001. ${ }^{11}$, in 12 The rate of loss exceeds that of the Missouri Coteau region of North Dakota (0.3\% loss/ year 1992-2002 ${ }^{13}$ ) and the Manitoba tall-grass prairie where overall prairie area exhibited an increase, despite $23 \%$ of studied grassland sites having been lost between 1987/1988 and 2006. ${ }^{14}$ World Wildlife Fund ${ }^{15}$ reports that the annual rate of overall grassland loss from 2011-2015 in the Canadian prairies ranged from $7 \%$ to $3 \%$, which was higher than the average annual loss of $2 \%$ observed in this study. However, the report did not distinguish between tame and native grasslands.

Despite some visual limitations of using roadside surveys, this approach produced relatively cost-effective mapping and a more accurate classification of grasslands than other remote-sensing approaches. Approximately $75 \%$ of grasslands could be classified as native or tame using this approach. In contrast, the classification accuracy for non-crop cover in Manitoba based on the 2016 AAFC land cover database was $68 \%$, and does not differentiate between native and non-native pasture. ${ }^{16}$

Prairie loss continues to occur within the three remaining large grassland blocks despite the efforts of conservation organizations in the IBA. This loss of habitat as well as the shift from native to tame grasslands could have implications on both availability and suitability of habitat for birds and other prairie species in the IBA. The results of this study suggest that conservation efforts in and/or alternative methods considered. To ensure prairie and the species that depend on it persist and flourish in Manitoba, we believe it is important that a variety of approaches to conserving them be used. Focused conservation efforts should be tailored to the unique socio-economic considerations of different regions, and could include:

- Supporting local grassland conservation champions (funding, research, in-kind).

- Perpetual securement of mixedgrass prairie, prioritizing large, intact blocks, including permanent protection from development.

- Supporting and contributing to the maintenance or expansion of compatible grassland-dependent economic development, such as a sustainable livestock industry.

- Develop and support programs to provide incentives and certification for livestock production practice that follow habitat-friendly practices.

- Building the knowledge base and capacity to conduct and scale up effective prairie restoration.

- Increasing the connectivity of mixed-grass prairie to: increase block size, buffer impacts from intensive agriculture and other land uses that are incompatible with grassland bird breeding and provide betweenblock movement corridors for prairie insects and other animals. the IBA may need to be accelerated, 


\section{Acknowledgements}

An earlier version of this manuscript was presented as a poster at the 2016 Prairie Conservation and Endangered Species Conference.

Jaimee Dupont Morozoff, Josh Dillabough, and Stephen Gietz contributed to field data collection. Stephen Gietz also provided GIS support and data management. Megan Westphal and Jordan Becker supported manuscript development. Thank you to Tim Poole of the Manitoba Important Bird Areas program for reviewing an earlier version of this manuscript, and to Stephen Davis whose constructive review improved the final draft. This project was undertaken as part of development of NCC's West Souris Mixed-grass Prairie Natural Area Conservation Plan, which was supported by the Province of Manitoba and Government of Canada's Natural Areas Conservation Program.

\section{References}

1. Manitoba Conservation Data Centre. 2017. Biotics Rare Elements Database. Manitoba Conservation Data Centre, Winnipeg, Manitoba.

2. Ribic, C. A., R.R. Koford, J.R. Herkert, D.H. Johnson, N.D. Niemuth, D.E Naugle, K.K Bakker, D.W Sample, and R. B. Renfrew. 2009. Perspectives in Ornithology: Area Sensitivity in North American Grassland Birds: Patterns and Processes. The Auk 126:233-244.

3. Davis, S.K. and D.C. Duncan. 1999. Grassland Songbird Occurrence in Native and Crested Wheatgrass Pastures of Southern Saskatchewan. Studies in Avian Ecology 19:211-218.

4. Davis, S. K., D. C. Duncan, and M. A. Skeel. 1999. Distribution and habitat associations of three endemic grassland songbirds in southern Saskatchewan. Wilson Bulletin 111:389-396.

5. Sliwinski, M.S. and N. Koper. 2012. Grassland Bird Responses to Three Edge Types in a Fragmented Mixed-Grass Prairie. Avian Conservation and Ecology 7(2):6.
6. Lindgren, C.J. and K. De Smet. 2001. Community Conservation Plan for the Southwestern Manitoba Mixed-grass Prairie Important Bird Area. Prepared for the Canadian Nature Federation, Bird Studies Canada, BirdLife International and the Manitoba Naturalists Society. Winnipeg, Manitoba. 50 pp.

7. Neufeld, R. and C. Hamel. 2017. West Souris Mixed-grass Prairie Natural Area Plan Summary. The Nature Conservancy of Canada, Winnipeg, MB. 10 pp. Available at: http://www.natureconservancy.ca/en/wherewe-work/manitoba/our-work/west_souris_ mixed-grass_prairie_natural_area.html

8. Manitoba Sustainable Development. 2017. Protected Areas Initiative. Available at: http://www.gov.mb.ca/sd/pai/index.html

9. Riley, J.L., S.E Green and, K.E. Brodribb. 2007. A Conservation Blueprint for Canada's Prairies and Parklands. The Nature Conservancy of Canada, Toronto, ON. Available at: http://support. natureconservancy.ca/pdf/blueprints/Prairies_ and_Parklands.pdf

10. Fitzgerald, J.A., D.N. Pashley and B. Pardo. 1999. Partners in Flight Bird Conservation Plan for The Northern Mixedgrass Prairie (Physiographic Area 37). Version 1.0. American Bird Conservancy Report, Jefferson City, Missouri. 65 pp. Available at: https://www.partnersinflight.org/wpcontent/uploads/2017/02/PA-37-NorthernMixed-Grass-Prairie.pdf

11. Watmough M.D., and M.J. Schmoll. 2007. Environment Canada's Prairie \& Northern Region Habitat Monitoring Program Phase II: Recent habitat trends in the Prairie Habitat Joint Venture.

Technical Report Series \# 493, Canadian Wildlife Service Prairie and Northern Region. Edmonton, Alberta. 135 pp.

12. M-over-C Land and Cattle Company Ltd \& J. MacKenzie. 2011. Literature Review-Quantity of Native Prairie Remaining in Saskatchewan. Prepared for the Saskatchewan Prairie Conservation Action Plan. 15 pp. Available at: http://www.pcapsk.org/rsu_docs/documents/PCAP_native_ prairie_lit_review_final_13Apr11.pdf

13. Stephens S.E., Walker J.A., Blunck D.R., Jayaraman A., Naugle D.E., Ringelman J.K., and A.J. Smith. 2008. Predicting Risk of Habitat Conversion in Native Temperate Grasslands. Conservation Biology 22:13201330.
14. Koper N., Mozel K.E., and D. Henderson. 2010. Recent declines in northern tall-grass prairies and effects of patch structure on community persistence. Biological Conservation 143:220-229.

15. World Wildlife Fund: Northern Great Plains Program. 2016. 2016 Plowprint Report Facts \& Figures. Bozeman, MT. 8 pp. Available at: http://assets.worldwildlife.org/ publications/947/files/original/plowprint_ AnnualReport_2016_Final_REV09192016. pdf?1474408576

16. Agriculture and Agri-food Canada. Undated. ISO 19131 Annual Crop Inventory - Data Product Specifications. Available at: https://open.canada.ca/data/en/dataset/ ba2645d5-4458-414d-b196-6303ac06c1c9.

POETRY

\section{The Expositional Snow}

What is it about snow

attracts all of us so--

its sparkle and shimmer

that slowly grows dimmer

its one solid blueness

declaring a newness

to cold winter's façade?

Then all creatures abroad

ghostly owls yet astir

hidden hares in white fur

wait on what's opportune

till a yellowy moon

climbs up the dark sky and

lightens the snow-blue land.

\author{
Victor C. Friesen \\ P.O. Box 65 \\ Rosthern, SK SOK 3RO \\ victorcfriesen@yahoo.com
}

